\title{
ОБГРУНТУВАННЯ ЗНАЧЕННЯ МЕТОДИКИ ЛІНІЙ ПРАКТИЧНИХ НАВИЧОК ДЛЯ ТЕОРЕТИЧНОЇ ТА ПРАКТИЧНОЇ ПІДГОТОВКИ СТУДЕНТІВ-МЕДИКІВ
}

\author{
О. О. Стаханська
}

\author{
ДВНЗ “Тернопільський державний медичний університет \\ імені І. Я. Горбачевського МОЗ Украӥни"
}

\section{SUBSTANTIATION OF METHODS IMPORTANCE OF PRACTICAL SKILLS LINES FOR THEORETICAL AND PRACTICAL TRAINING OF MEDICAL STUDENTS}

\author{
O. O. Stakhanska \\ SHEI "Ternopil State Medical University by I. Ya. Horbachevsky of MPH of Ukraine”
}

\begin{abstract}
У роботі обгрунтовується ефективність використання методики ліній практичних навичок у теоретичній та практичній підготовці студентів-медиків.
\end{abstract}

In this work we establish efficiency of application of practical skills lines for theoretical and practical training of stomatological students.

Вступ. Інтеграція у світовий медичний освітній простір вимагає розробки інноваційних навчальних методик. Про необхідність підвищення кваліфікації лікарських кадрів свідчать стандарти ВООЗ, нові технології, сучасні алгоритми, які вимагають безперервного покращення якості медичної допомоги та максимальної ії ефективності. Провідне місце у цьому належить саме рівню кваліфікації фахівців. Обсяг наукової інформації щороку зростає, підвищуються вимоги до рівня підготовки спеціалістів, хоча навчальний процес на додипломному етапі не може бути значно збільшений. Вирішення цієї суперечності може бути лише одне - інтенсифікувати навчання за рахунок впровадження інноваційних методик [1].

Одним із шляхів модернізації освітньої системи України постає упровадження в навчальний процес ВНЗ інноваційних педагогічних технологій і методів. Інновації (італ. innovatione - новизна, нововведення) - нові форми організації діяльності і управління, нові види технологій, які охоплюють різні сфери життєдіяльності людства [2].

Педагогічну інновацію розглядають як особливу форму педагогічної діяльності і мислення, які спрямовані на організацію нововведень в освітньому просторі, або як процес створення, упровадження і поши-

(c) О. О. Стаханська рення нового в освіті. Інноваційний процес в освітіце сукупність послідовних, цілеспрямованих дій, спрямованих на ії̈ оновлення, модифікацію мети, змісту, організації, форм і методів навчання та виховання, адаптації навчального процесу до нових суспільноісторичних умов [3].

Мета даної роботи - дослідити ефективність використання студентами-медиками інноваційної методики ліній практичних навичок для теоретичної та практичної підготовки.

Основна частина. Матрикул практичних навичок - це перелік практичних навичок, який складений кафедрами на основі галузевих стандартів освіти (освітньо-кваліфікаційної характеристики) і $є$ обов'язковим для опанування студентом протягом навчального року. Практичні навички розподілені по курсах, які у матрикулах названі лініями. Рік навчання відповідає номеру лінії. Половина практичних навичок однієї лінії повинна бути здана протягом осіннього семестру.

Здавати практичні навички викладачу студенти можуть як під час проведення практичної частини занять, так і під час позааудиторної самостійної роботи. Під час опанування практичної навички викладач створює всі умови для студента, а також може проконсультувати його щодо методики та техніки іiі виконання і при потребі практично продемонструва- 
ти. Студент має право самостійного вибору часу здачі кожної навички, кафедри (серед тих, які можуть їі зарахувати) та викладача (при умові, що він відповідає за ведення відповідного циклу), якому буде ії здавати.

Кожній із практичних навичок присвоєно один 3 наступних рівнів опанування.

Перший рівень вимагає лише теоретичного розуміння студентом всіх етапів їі виконання і виявляється шляхом опитування студента.

Для засвоєння другого рівня студент мусить, окрім розуміння навички, хоча б раз побачити її виконання на практиці (виконання маніпуляції, процедури або пацієнта з відповідним захворюванням тощо). Виявляється шляхом опитування студента щодо техніки виконання навички та подальшої присутності його під час виконання навички.

Третій рівень передбачає виконання студентом навички на муляжі, фантомі чи в лабораторних умовах.

Для отримання четвертого рівня студент повинен провести маніпуляцію в лабораторії, клініці на хворому під наглядом викладача. Викладач може проводити невеликі корективи.

Найскладнішим є п'ятий рівень, відмітку про виконання якого виставляється за умови самостійного виконання студентом практичної навички в лабораторних умовах або на пацієнті.

Здача навички, окрім практичного виконання, передбачає грунтовне знання і розуміння студентом іiі теоретичних аспектів.

Тому, приймаючи у студента практичну навичку 2-го і вище рівня, викладач попередньо обов' язково повинен переконатись шляхом опитування, чи знає студент методику їі виконання.

Рівень оволодіння повинен бути не нижчий, ніж зазначений у матрикулі щодо кожної навички зокрема. Курація хворого передбачає не лише кількаразове відвідування стаціонарного (чи прийом амбулаторного) пацієнта з відповідним діагнозом, присутність при проходженні хворим протягом цього часу діагностичних процедур (УЗД, ЕКГ, ЕГДС тощо), але й знання даної патології, методів їі діагностики, лікування.

Викладач, який прийняв практичну навичку, ставить у відповідній графі матрикула студента відмітку “зараховано”, записує назву кафедри, дату здачі навички, вчене звання, своє прізвище, ім'я, по батькові та особистий підпис. У випадку незарахування навички місце запису залишається пустим. 3 метою належної теоретичної підготовки і практичного за- своєння незарахованої навички перездача допускається не раніше ніж через 2 дні.

Відмітка про здачу студентом практичної навички вноситься викладачем також у додаток до журналу академічної успішності студентів групи. Після завершення осіннього семестру матрикул подається у деканат для підрахунку відсотка зданих навичок. Після завершення навчального року і зарахування усіх практичних навичок даної лінії матрикул здається у деканат і зберігається в архіві, як інші документи про успішність студентів. Несвоєчасне виконання матрикула є підставою для недопущення студента до екзаменаційної сесії та відрахування його з університету.

Вивчаючи вплив опанування студентами-медиками ліній практичних навичок на рівень теоретичних знань та практичної компетентності, було проведене статистичне дослідження. В дослідженні брали участь 242 студенти 4-го курсу медичного факультету. Студенти були розбиті на дві групи: дослідну (122 студенти 2009/10 н. р.) та контрольну (120 студентів 2009/ 10 н. р.). Студенти контрольної групи опановували курс у звичайному форматі, а дослідної- той самий курс, складаючи четверту лінію практичних навичок.

3 метою перевірки ефективності складання лінії практичних навичок для опанування теоретичних знань було використано семестровий тестовий іспит 3 нервових хвороб (24 завдання, включаючи тести 3 короткими відповідями, запитання до графічних зображень та ситуаційні задачі).

Як інструмент визначення впливу складання лінії практичних навичок на рівень практичної компетенції студентів використано стандартизовану методику OCKI, яка передбачає проходження студентом 12 робочих станцій.

Здійснили порівняння результатів тестового іспиту для перевірки ефективності лінії практичних навичок для опанування теоретичних знань. Отримані результати наведені в таблиці 1.

Після завершення проходження курсу також було здійснене спеціальне анонімне анкетування, метою якого була оцінка ефективності складання ліній практичних навичок на основі відповідей студентів.

Нижче наведено результати відповідей на основі запитання щодо загальної характеристики навчального курсу (табл. 2).

Як можна бачити 3 наведеної таблиці 2, для значної кількості студентів обох груп матеріал курсу був складним. Підкреслимо, що статистично достовірних розходжень між дослідною та контрольною гру- 
Таблиця 1. Зіставлення позитивних відповідей залежно від виду тестових завдань

\begin{tabular}{|c|c|c|c|c|c|c|}
\hline \multirow{3}{*}{ Вид завдання } & \multirow{3}{*}{$\begin{array}{c}\text { Кількість } \\
\text { завдань }\end{array}$} & \multicolumn{4}{|c|}{ Група студентів } & \multirow{3}{*}{$\mathrm{p}$} \\
\hline & & \multicolumn{2}{|c|}{ контрольна $(\mathrm{n}=120)$} & \multicolumn{2}{|c|}{ основна $(\mathrm{n}=122)$} & \\
\hline & & абс. & $\%$ & абс. & $\%$ & \\
\hline $\begin{array}{l}3 \text { відкритими } \\
\text { короткими } \\
\text { відповідями }\end{array}$ & 9 & 689 & 63,8 & 675 & 61,5 & $>0,05$ \\
\hline $\begin{array}{l}3 \text { графічними } \\
\text { зображеннями }\end{array}$ & 12 & 978 & 67,9 & 1012 & 69,1 & $>0,05$ \\
\hline $\begin{array}{l}\text { У вигляді } \\
\text { ситуаційних задач }\end{array}$ & 3 & 209 & 58,1 & 275 & 75,1 & $<0,05$ \\
\hline
\end{tabular}

Таблиця 2. Результати відповідей на основі запитання щодо загальної характеристики навчального курсу

\begin{tabular}{|c|c|c|c|c|c|}
\hline \multirow{3}{*}{ Питання анкети } & \multicolumn{4}{|c|}{ Група студентів } & \multirow{3}{*}{$\mathrm{p}$} \\
\hline & \multicolumn{2}{|c|}{ контрольна $(\mathrm{n}=120)$} & \multicolumn{2}{|c|}{ основна $(\mathrm{n}=122)$} & \\
\hline & абс. & $\%$ & абс. & $\%$ & \\
\hline Чи був складним матеріал курсу & 95 & 79,2 & 92 & 75,4 & $>0,05$ \\
\hline $\begin{array}{l}\text { Чи отримали Ви міцні знання } 3 \text { даного } \\
\text { курсу }\end{array}$ & 78 & 65 & 83 & 68 & $>0,05$ \\
\hline $\begin{array}{l}\text { Чи отримали Ви ефективні практичні } \\
\text { навички з даного курсу }\end{array}$ & 75 & 62,5 & 103 & 84,4 & $<0,05$ \\
\hline $\begin{array}{l}\text { Чи повною мірою супроводжувався } \\
\text { виклад курсу демонстрацією } \\
\text { практичних навичок на фантомах }\end{array}$ & 109 & 90,8 & 112 & 91,8 & $>0,05$ \\
\hline $\begin{array}{l}\text { Чи повною мірою супроводжувався } \\
\text { виклад курсу демонстрацією } \\
\text { практичних навичок на пацієнтах }\end{array}$ & 112 & 93,3 & 115 & 94,3 & $>0,05$ \\
\hline
\end{tabular}

пами тут не виявлено ( $>>0,05)$. Це ж стосується, відповідаючи на усі інші запитання. Водночас отримано достовірні зміни в сторону покращення при використанні лінії практичних навичок при самооцінці рівня практичної компетентності.

Висновки. Аналіз результатів ефективності використання методики матрикулів практичних навичок для студентів-медиків свідчить про його суттєве значення для організації навчального процесу на сучасному етапі.

1. Тут, у першу чергу, слід відзначити наскрізний

\section{Література}

1. Ковальчук Л. Я. Впровадження новітніх методик і систем навчального процесу в Тернопільському державному медичному університеті ім. І. Я. Горбачевського / Л. Я. Ковальчук// Медична освіта. -2009. -№ 2. - С. 10-14. характер методики через усі навчальні дисципліни, що дозволяє інтегрувати отримані студентамимедиками знання при опануванні конкретних навиків.

2. Для запровадження ліній практичних навичок важливим $є$ наповнення мультимедійними ресурсами, такими, як відеозаписи практичних навичок, операцій та маніпуляцій, аудіозаписи тонів серця і інших внутрішніх органів тощо.

3. Методика матрикулів практичних навичок сприяє розвитку клінічного мислення у студентів-медиків.

2. Положення про порядок здійснення інноваційної освітньої діяльності // Освіта України. - 2001. - № 6. - С. 17-18.

3. Баханов К. Шляхи інноваційного навчання / К. Баханов // Історія в школах України. - 1999. - № 4. - С. 19-25. 